\title{
Changing Lifestyle of Women -An Empirical Study
}

\author{
Adeel Maqbool, Rizwana Atiq \\ Department of Business Management Integral University, Kursi Road, Lucknow, India
}

\begin{abstract}
This research had been conducted to see whether there has been a change in the lifestyle of women or not. To achieve the objectives of the study, a total 270 middle class women respondents have been selected from Lucknow and Delhi. A well structured questionnaire has been drafted to get the information regarding the lifestyle of women. As we know that market cannot operate without the consumer so, the consumer is known as the soul for the market. Women as consumers are also participating in buying the goods. Now-a-days Indian women are dominating the market by making their presence in every purchase decision. So, it is also required to know whether the lifestyle of women is the same as two decades back or has changed. An effort has been made to judge the Indian women's change in consumption pattern because of the any change in lifestyle. A few aspects are considered to see if lifestyle has changed on those fronts. For this women are grouped in two sections. The first indicates women in the age group of 21-40 years of age which is taken sroup one and the other group comprises of women who are more than 40 years old which is taken as group two.. The paper tries to see if women get time to cook at home, whether they take a proper lunch everyday, whether their daily routine involves considerable physical activity, whether they get sufficient time to spend with their families, whether they are involved in shopping for their families, whether they prefer to save money or spend on their present comfort and few more related questions. These questions are asked to see if women are the same as they were in the previous years or there is some change in their lifestyle. The study also tries to see if the consumption of any product or services may change because of any change in any aspect of lifestyle.

Keywords: Middle Class, Consumption, Disposable Income.
\end{abstract}

\section{Introduction}

The Indian market needs to think in favour of the fairer sex. Now-a-days women are not only playing role of hardcore 'housewives', they are also playing a different role of 'chief purchaser' in their families. They are working as multi-tasker by playing a role of house maker as well as professional women with their hard work. With their new role as a professional, there has been a gradual change in the lifestyle of women. According to ICAER middle class means individuals whose annual household income is between 3.4 to 17 lakhs.

\section{Review Of Literature}

A lot of studies have been conducted by many researchers, practitioners and professional on the lifestyle of women in India and all over the world. Martha Barlett suggests in her study "marketing to Women" is ideal to target the women, as it helps to enhance the returns due to the loyalty and referral power of women in the long run. Further, she opines that the natural behavior of women to talk and share experiences adds fillip to the marketing process by the multiplier effect of word of mouth. Simintiras \& Anotonis (1997) attempt to distinguish evaluation outcomes of likely future satisfaction from feelings or emotions prior to the act of purchase, and assess the impact of pre-purchase satisfaction on the purchase behaviour of first time buyers. Shainesh (2004) presents that marketers have been remarkably remiss in not looking at women as a separate segment. Dr.M.Subrahmanian (2011) examine in his study "buying behavior of the new aged Indian women" in the city of Chennai" with respect to the age, marital status, occupation, professional status factors, etc. to identify the decision maker and the influencer for the purchase made by the women. According to this study the women's value perception is multi-faceted and they are more quality oriented. When it comes to the price attribute women do not opt for the products even if it is heavily priced or low priced but to the maximum prefer when it is reasonably priced within the affordable range.

\section{Objectives Of The Study}

In this study I have decided the following objectives -

1. To find out if the lifestyle of women has changed related to food and fitness factor.

2. To know if outlook of women in relation to spending is the same as two decades back or has changed. 


\section{Research Methodology}

The study "Changing Lifestyle of Women-An Empirical Study" analyzes women on the basis of primary data. Primary data for the study is collected through questionnaire and personal comments from the respondents. The primary data has been collected from Delhi and Lucknow to study the lifestyle of the women there. A sample size of 270 middle class women consumers of two age groups,one aged between 21-40 years old and other above 40 years old has been considered.

Hypothesis No.1 :

HO1: There is no significant difference between age of the respondents and the time they get to cook food at home . $(\mu=3)$

H1: There is significant difference between age of the respondents and the time they get to cook food at home. $(\mu \neq 3)$

Hypothesis No.2 :

HO: There is no significant difference between age of the respondents and whether they take a proper lunch everyday. $(\mu=3)$

H1: There is significant difference between age of the respondents and whether they take a proper lunch everyday. $(\mu \neq 3)$

Hypothesis No.3 :

HO: There is no significant difference between age of the respondents and the considerable physical activity they do in their daily routine. $(\mu=3)$

H1: There is significant difference between age of the respondents and the considerable physical activity do in their daily routine. $(\mu \neq 3)$

Hypothesis No.4:

HO: There is no significant difference between age of the respondents and the sufficient time they get to spend with their family . $(\mu=3)$

H1: There is significant difference between age of the respondents and the sufficient time they get to spend with their family. $(\mu \neq 3)$

Hypothesis No. 5:

HO: There is no significant difference between age of the respondents and doing most of the shopping for their families. $(\mu=3)$

H1: There is significant difference between age of the respondents and doing most of the shopping for their families $(\mu \neq 3)$

Hypothesis No.6:

HO: There is no significant difference between age of the respondents and I prefer to save money for future than spend most of it on present comfort. $(\mu=3)$

H1: There is significant difference between age of the respondents and the preference for saving money for fture. $(\mu \neq 3)$.

Hypothesis No. 7 :

HO: There is no significant difference between age of the respondents and spending products having public view. $(\mu=3)$

H1: There is significant difference between age of the respondents and spending on products having public view. $(\mu \neq 3)$

Hypothesis No.8:

HO: There is no significant difference between age of the respondents and the desire to use the latest model of mobile even if they don't use many of the high tech. features. $(\mu=3)$

H1: There is significant difference between age of the respondents and the the desire to use the latest Hypothesis No.9 :

model of mobile even if they don't use many of the high tech. features. $(\mu \neq 3)$

HO: There is no significant difference between age of the respondents and the wish to have their house in a posh colony as compared to a place close to the market or work place. $(\mu=3)$

H1: There is significant difference between age of the respondents and the wish to have their house in a posh colony as compared to a place close to the market or work place. $(\mu \neq 3)$

\section{Analysis And Interpretation Of The Study}

The research has been carried out with the objective to examine if there has been a change in the lifestyle of middle class women in Delhi and Lucknow. Of all the women respondents $62 \%$ women belongs to salaried class, $2 \%$ business class, \& $36 \%$ women are house wives. They belong to different age groups, $50 \%$ are in 21-40 years age group, 50\% are above 40 years age group, Out of the working women 5\% women in the age group of 21-40 have an annual income less than 3.4 lakhs. $10 \%$ have an annual income of above 3.4 lakhs up to 6.8 lakhs, $50 \%$ above 6.8 up to 10.2 lakhs, $15 \%$ above 10.2 up to 13.6 lakhs $20 \%$ above 13.6 up to 17 lakhs. 
While out of the working women above 40 years of age $25 \%$ women in the age group of 21-40 have an annual income less than 3.4 lakhs. $65 \%$ have an annual income of above 3.4 lakhs up to 6.8 lakhs, $9 \%$ above 6.8 up to 10.2 lakhs , $1 \%$ above 10.2 up to 13.6 lakhs $20 \%$ and none above 13.6 up to 17 lakhs.

Hypothesis No.1 :

HO1: There is no significant difference between age of the respondents and the time they get to cook food at home . $(\mu=3)$

H1: There is significant difference between age of the respondents and the time they get to cook food at home . $(\mu \neq 3)$

age group * f time Cross tabulation

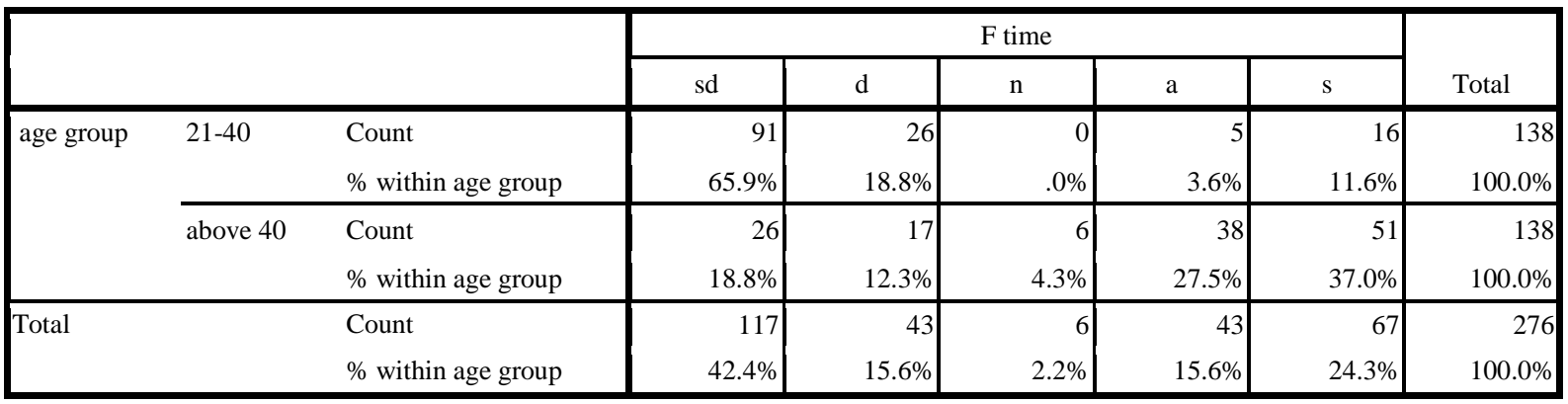

\begin{tabular}{|c|c|c|c|}
\hline \multicolumn{4}{|c|}{ Chi-Square Tests } \\
\hline & Value & df & $\begin{array}{l}\text { Asymp. Sig. (2- } \\
\text { sided) }\end{array}$ \\
\hline Pearson Chi-Square & $87.604^{\mathrm{a}}$ & 4 & .000 \\
\hline Likelihood Ratio & 96.381 & 4 & .000 \\
\hline Linear-by-Linear Association & 74.261 & 1 & .000 \\
\hline $\mathrm{N}$ of Valid Cases & 276 & & \\
\hline $\mathrm{N}$ of Valid Cases & 276 & & \\
\hline
\end{tabular}

Findings: As per the analysis of Chi-square test the calculated value of Chi-square with $95 \%$ level of confidence is 0.000 which is less than level of significance i.e. 0.05 . So there is significant difference in the time which respondents get to cook food at home when it is compared with age group of respondents between $21-$ 40 years \& above 40 years with the responses of the statement that I get sufficient time to cook food at home.

Interpretation: Women in the age group of 21-40 do not get sufficient time to cook at home while above 40 years say that they get sufficient time to cook at home. Since the younger women do not get time to cook then there is a probability that they will either go to the restaurants to eat, which will thereby increase the consumption of food sold in the restaurants or else if they at all try to cook at home then they will try and keep readymade spices which may save their time in the kitchen. There is an another probability that the young women may keep a maid to cook food .Further results will help us find out which of the following has taken a lead to keep in pace the changed lifestyle of women of getting sufficient time to cook at home.

Hypothesis No.2 :

HO: There is no significant difference between age of the respondents and whether they take a proper lunch everyday. $(\mu=3)$

H1: There is significant difference between age of the respondents and whether they take a proper lunch everyday. $(\mu \neq 3)$

\begin{tabular}{|c|c|c|c|c|c|c|c|}
\hline & & & \multicolumn{4}{|c|}{ flun } & \multirow[b]{2}{*}{ Total } \\
\hline & & & sd & $\mathrm{d}$ & $\mathrm{a}$ & s & \\
\hline \multirow[t]{4}{*}{ age group } & \multirow[t]{2}{*}{$21-40$} & Count & 92 & 25 & 1 & 20 & 138 \\
\hline & & $\%$ within age group & $66.7 \%$ & $18.1 \%$ & $.7 \%$ & $14.5 \%$ & $100.0 \%$ \\
\hline & \multirow[t]{2}{*}{ above 40} & Count & 26 & 23 & 26 & 63 & 138 \\
\hline & & $\%$ within age group & $18.8 \%$ & $16.7 \%$ & $18.8 \%$ & $45.7 \%$ & $100.0 \%$ \\
\hline Total & & Count & 118 & 48 & 27 & 83 & 276 \\
\hline
\end{tabular}




\begin{tabular}{|c|c|c|c|c|c|c|c|}
\hline & & & \multicolumn{4}{|c|}{ flun } & \multirow[b]{2}{*}{ Total } \\
\hline & & & sd & $\mathrm{d}$ & $\mathrm{a}$ & s & \\
\hline \multirow[t]{4}{*}{ age group } & $21-40$ & Count & 92 & 25 & 1 & 20 & 138 \\
\hline & & $\%$ within age group & $66.7 \%$ & $18.1 \%$ & $.7 \%$ & $14.5 \%$ & $100.0 \%$ \\
\hline & above 40 & Count & 26 & 23 & 26 & 63 & 138 \\
\hline & & $\%$ within age group & $18.8 \%$ & $16.7 \%$ & $18.8 \%$ & $45.7 \%$ & $100.0 \%$ \\
\hline \multirow[t]{2}{*}{ Total } & & Count & 118 & 48 & 27 & 83 & 276 \\
\hline & & $\%$ within age group & $42.8 \%$ & $17.4 \%$ & $9.8 \%$ & $30.1 \%$ & $100.0 \%$ \\
\hline
\end{tabular}

\begin{tabular}{|c|c|c|c|}
\hline \multicolumn{4}{|c|}{ Chi-Square Tests } \\
\hline & Value & df & $\begin{array}{l}\text { Asymp. Sig. (2- } \\
\text { sided) }\end{array}$ \\
\hline Pearson Chi-Square & $82.424^{\mathrm{a}}$ & 3 & .000 \\
\hline Likelihood Ratio & 91.490 & 3 & .000 \\
\hline Linear-by-Linear Association & 70.445 & 1 & .000 \\
\hline $\mathrm{N}$ of Valid Cases & 276 & & \\
\hline
\end{tabular}

Finding: As per the analysis of Chi-square test the calculated value of Chi-square with $95 \%$ level of confidence is 0.000 which is less than level of significance i.e. 0.05. So there is significant difference in life style of respondents when it is compared with age group of respondents between $21-40$ years \& above 40 years with the responses of the statement that I take a proper lunch everyday..

Interpretation: Women in the age group of 21-40 do not take a proper lunch every day . While women in the age group above 40 do take proper lunch everyday. The women who are not taking a proper lunch everyday may either be consuming juice or eating snacks or may be staying hungry. It is seen that most of the women in the 21-40 age group want to look fit and it is also seen that most of the women in this age group consume juice on a daily basis. Thus we can see that there is greater consumption of juice in the age group 21-40. Thus there is a shift in the consumption from taking proper lunch to consuming juice.

Hypothesis No.3 :

HO: There is no significant difference between age of the respondents and the considerable physical activity they do in their daily routine. $(\mu=3)$

H1: There is significant difference between age of the respondents and the considerable physical activity do in their daily routine. $(\mu \neq 3)$.

Finding: As per the analysis of Chi-square test the calculated value of Chi-square with $95 \%$ level of confidence is 0.000 which is less than level of significance i.e. 0.05. So there is significant difference in life style of respondents when it is compared with age group of respondents between $20-40$ years \& above 40 years with the responses of the statement that "my daily routine involves considerable physical activity."

Interpretation: Women in the age group of 21-40 say that their daily routine does nor involve physical activity while the daily routine of most of the women above 40 does involve physical activity. Since most of the 21-40 age group women want to look fit but their routine does not involve physical activity,

\begin{tabular}{|c|c|c|c|c|c|c|c|}
\hline & & & \multicolumn{4}{|c|}{ fphy } & \multirow[b]{2}{*}{ Total } \\
\hline & & & sd & $\mathrm{d}$ & $\mathrm{a}$ & $\mathrm{s}$ & \\
\hline \multirow[t]{4}{*}{ age group } & $21-40$ & Count & 117 & 0 & 0 & 21 & 138 \\
\hline & & $\%$ within age group & $84.8 \%$ & $.0 \%$ & $.0 \%$ & $15.2 \%$ & $100.0 \%$ \\
\hline & above 40 & Count & 26 & 17 & 36 & 59 & 138 \\
\hline & & $\%$ within age group & $18.8 \%$ & $12.3 \%$ & $26.1 \%$ & $42.8 \%$ & $100.0 \%$ \\
\hline \multirow[t]{2}{*}{ Total } & & Count & 143 & 17 & 36 & 80 & 276 \\
\hline & & $\%$ within age group & $51.8 \%$ & $6.2 \%$ & $13.0 \%$ & $29.0 \%$ & $100.0 \%$ \\
\hline
\end{tabular}

Chi-Square Tests 


\begin{tabular}{|c|c|c|c|}
\hline & Value & df & $\begin{array}{l}\text { Asymp. Sig. (2- } \\
\text { sided) }\end{array}$ \\
\hline Pearson Chi-Square & $1.290 \mathrm{E} 2^{\mathrm{a}}$ & 3 & .000 \\
\hline Likelihood Ratio & 154.908 & 3 & .000 \\
\hline Citation & 84.615 & 1 & .000 \\
\hline $\mathrm{N}$ of Valid Cases & 276 & & \\
\hline
\end{tabular}

a. 0 cells $(.0 \%)$ have expected count less than 5 . The minimum expected count is 8.50 .

there is a probability that the younger women would either go to the gym to stay fit or/ and eat healthy food to stay fit. But since most of the women have already said that they do not get the time to cook food neither do they have to do most of their work. So in order to stay fit women would go to the gym or yoga centres. This will increase the consumption of health services the market.

Hypothesis No.4 :

HO: There is no significant difference between age of the respondents and the sufficient time they get to spend with their family . $(\mu=3)$

H1: There is significant difference between age of the respondents and the sufficient time they get to spend with their family . $(\mu \neq 3)$

\begin{tabular}{|c|c|c|c|c|c|c|}
\hline & & & \multicolumn{3}{|c|}{ Fspen } & \multirow[b]{2}{*}{ Total } \\
\hline & & & sd & $\mathrm{a}$ & $\mathrm{s}$ & \\
\hline \multirow[t]{4}{*}{ age group } & $21-40$ & Count & 117 & 6 & 15 & 138 \\
\hline & & $\%$ within age group & $84.8 \%$ & $4.3 \%$ & $10.9 \%$ & $100.0 \%$ \\
\hline & above 40 & Count & 53 & 5 & 80 & 138 \\
\hline & & $\%$ within age group & $38.4 \%$ & $3.6 \%$ & $58.0 \%$ & $100.0 \%$ \\
\hline \multirow[t]{2}{*}{ Total } & & Count & 170 & 11 & 95 & 276 \\
\hline & & $\%$ within age group & $61.6 \%$ & $4.0 \%$ & $34.4 \%$ & $100.0 \%$ \\
\hline
\end{tabular}

\begin{tabular}{|l|r|r|r|}
\hline & \multicolumn{1}{|c|}{ Chi-Square Tests } \\
\hline Value & df & $\begin{array}{c}\text { Asymp. Sig. (2- } \\
\text { sided) }\end{array}$ \\
\hline Pearson Chi-Square & $68.659^{\mathrm{a}}$ & 2 & .000 \\
Likelihood Ratio & 73.616 & 2 & .000 \\
Linear-by-Linear Association & 65.744 & 1 & .000 \\
$\mathrm{~N}$ of Valid Cases & 276 & & \\
\hline
\end{tabular}

Finding: As per the analysis of Chi-square test the calculated value of Chi-square with $95 \%$ level of confidence is 0.000 which is less than level of significance i.e. 0.05 . So there is significant difference in life style of respondents when it is compared with age group of respondents between $20-40$ years \& above 40 years with the responses of the statement I get sufficient time to spend with my family.

Interpretation: Women in the age group of 21-40 say that they do not get sufficient time to spend with their families. While women above 40 do get the time to spend with their families. This is a great change in the lifestyle of women. Although women see themselves as a strong pillar in keeping their families happy but they do not have time to spend with their families. Not only this it is also seen that most of the women in the 21-40 age group have a personal income which is more than the women above 40. All these aspects indicate that to overcome the lifestyle change of not being able to spend time with family on a daily basis, the women go on a tour with their families in almost every vacation. This inclination on going on a tour will increase the consumption pattern of tour services

Hypothesis No. 5:

HO: There is no significant difference between age of the respondents and doing most of the shopping for their families. $(\mu=3)$

H1: There is significant difference between age of the respondents and doing most of the shopping for their families $(\mu \neq 3)$ 


\begin{tabular}{|c|c|c|c|c|c|c|c|}
\hline & & & \multicolumn{4}{|c|}{ Fspen } & \multirow[b]{2}{*}{ Total } \\
\hline & & & sd & $\mathrm{d}$ & $\mathrm{a}$ & $\mathrm{s}$ & \\
\hline \multirow[t]{4}{*}{ age group } & $21-40$ & Count & 0 & 0 & 13 & 125 & 138 \\
\hline & & $\%$ within age group & $.0 \%$ & $.0 \%$ & $9.4 \%$ & $90.6 \%$ & $100.0 \%$ \\
\hline & above 40 & Count & 80 & 5 & 1 & 52 & 138 \\
\hline & & $\%$ within age group & $58.0 \%$ & $3.6 \%$ & $.7 \%$ & $37.7 \%$ & $100.0 \%$ \\
\hline \multirow[t]{2}{*}{ Total } & & Count & 80 & 5 & 14 & 177 & 276 \\
\hline & & $\%$ within age group & $29.0 \%$ & $1.8 \%$ & $5.1 \%$ & $64.1 \%$ & $100.0 \%$ \\
\hline
\end{tabular}

\begin{tabular}{|l|r|r|r|}
\hline & Chi-Square Tests & \multicolumn{2}{c|}{$\begin{array}{c}\text { Asymp. Sig. (2- } \\
\text { sided) }\end{array}$} \\
\hline Pearson Chi-Square & \multicolumn{1}{|c|}{ Value } & df & .000 \\
Likelihood Ratio & $1.254 \mathrm{E} 2$ & 3 & .000 \\
Linear-by-Linear Association & 161.063 & 3 & .000 \\
$\mathrm{~N}$ of Valid Cases & 115.798 & 1 & \\
\hline
\end{tabular}

Finding: As per the analysis of Chi-square test the calculated value of Chi-square with $95 \%$ level of confidence is 0.000 which is less than level of significance i.e. 0.05. So there is significant difference in life style of respondents when it is compared with age group of respondents between $20-40$ years \& above 40 years with the responses of the statement that I do most of the shopping for my family.

Interpretation: Since women in the age group of 21-40 do most of the shopping fr their families, it is quite probable that those products will be sold more in the market which are able to catch the attention of women. The marketers should understand the psychology of women and communicate the benefits of the products in order o increase the sale of their products.

Hypothesis No.6 :

HO: There is no significant difference between age of the respondents and I prefer to save money for future than spend most of it on present comfort. $(\mu=3)$

$\mathrm{H} 1$ : There is significant difference between age of the respondents and the preference for saving money for future. $(\mu \neq 3)$

\begin{tabular}{|c|c|c|c|c|c|c|c|}
\hline & & & \multicolumn{4}{|c|}{ msave } & \multirow[b]{2}{*}{ Total } \\
\hline & & & $\mathrm{sd}$ & D & $\mathrm{a}$ & $\mathrm{s}$ & \\
\hline \multirow[t]{4}{*}{ age group } & $21-40$ & Count & 135 & 3 & 0 & 0 & 138 \\
\hline & & $\%$ within age group & $97.8 \%$ & $2.2 \%$ & $.0 \%$ & $.0 \%$ & $100.0 \%$ \\
\hline & above 40 & Count & 52 & 1 & 7 & 78 & 138 \\
\hline & & $\%$ within age group & $37.7 \%$ & $.7 \%$ & $5.1 \%$ & $56.5 \%$ & $100.0 \%$ \\
\hline \multirow[t]{2}{*}{ Total } & & Count & 187 & 4 & 7 & 78 & 276 \\
\hline & & $\%$ within age group & $67.8 \%$ & $1.4 \%$ & $2.5 \%$ & $28.3 \%$ & $100.0 \%$ \\
\hline
\end{tabular}

\begin{tabular}{|c|c|c|c|}
\hline \multicolumn{4}{|c|}{ Chi-Square Tests } \\
\hline & Value & df & $\begin{array}{l}\text { Asymp. Sig. (2- } \\
\text { sided) }\end{array}$ \\
\hline Pearson Chi-Square & $1.228 \mathrm{E} 2^{\mathrm{a}}$ & 3 & .000 \\
\hline Likelihood Ratio & 157.037 & 3 & .000 \\
\hline Linear-by-Linear Association & 120.821 & 1 & .000 \\
\hline $\mathrm{N}$ of Valid & 276 & & \\
\hline
\end{tabular}

a. 4 cells $(50.0 \%)$ have expected count less than 5 . The minimum expected count is 2.00 . 
Finding: As per the analysis of Chi-square test the calculated value of Chi-square with $95 \%$ level of confidence is 0.000 which is less than level of significance i.e. 0.05. So there is significant difference in life style of respondents when it is compared with age group of respondents between $20-40$ years \& above 40 years with the responses of the statement that I prefer to save money for future than spend most of it on present comfort.

Interpretation: Women in the age group of 21-40 do not want to save money and on the same side they do have a considerably good salary than the women above 40. Having money and not wanting to save is showing a lifestyle change towards more spending. This spending lies in the hands of women aged 21-40. This increase in the spending will increase the consumption pattern of products and services which interest the women in the 2140 age group. This may increase the consumption of beauty products which attract women more. The research also shows that most of the women in this ge group can't resist purchasing apparel even if they have come to buy something else in the market. This shows a lot of spending will be on the women apparel.

Hypothesis No. 7:

HO: There is no significant difference between age of the respondents and spending products having public view. $(\mu=3)$

H1: There is significant difference between age of the respondents and spending on products having public view. $(\mu \neq 3)$ age group * view Cross tabulation

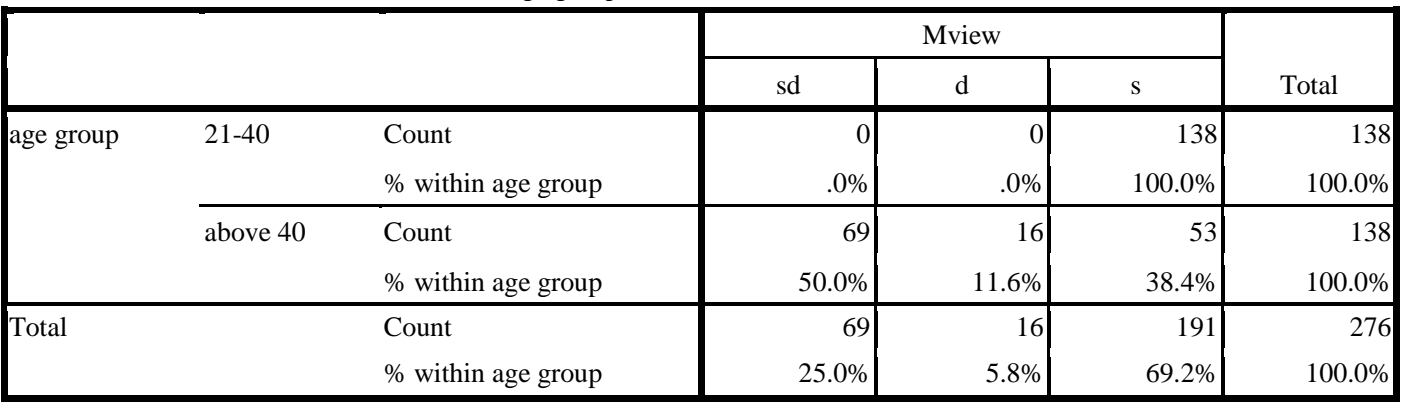

Finding: As per the analysis of Chi-square test the calculated value of Chi-square with $95 \%$ level of confidence is 0.000 which is less than level of significance i.e. 0.05. So there is significant difference in life style of respondents when it is compared with age group of respondents between $20-40$ years \& above 40 years with the responses of the statement that I prefer spending on products having public view.

Interpretation: Women in the age group of 21-40 prefer spending on products having public view. There is a shift $i$ the women interest towards a more show off which was is not the towards who are above 40 . This change in lifestyle will increase the consumption of all items which help to improve one's image in the society.

Chi-Square Tests

\begin{tabular}{|l|r|r|r|}
\hline & \multicolumn{1}{|c|}{ Value } & df & $\begin{array}{c}\text { Asymp. Sig. (2- } \\
\text { sided) }\end{array}$ \\
\hline Pearson Chi-Square & $1.228 \mathrm{E}^{\mathrm{a}}$ & 2 & .000 \\
Likelihood Ratio & 157.022 & 2 & .000 \\
Linear-by-Linear Association & 120.550 & 1 & .000 \\
$\mathrm{~N}$ of Valid Cases & 276 & & \\
\hline
\end{tabular}

Hypothesis No.8 :

HO: There is no significant difference between age of the respondents and the desire to use the latest model of mobile even if they don't use many of the high tech. features. $(\mu=3)$

H1: There is significant difference between age of the respondents and the desire to use the latest model of mobile even if they don't use many of the high tech. features. $(\mu \neq 3)$

\begin{tabular}{|c|c|c|c|c|c|c|}
\hline & & & \multicolumn{3}{|c|}{ Mmob } & \multirow[b]{2}{*}{ Total } \\
\hline & & & sd & $\mathrm{d}$ & $\mathrm{s}$ & \\
\hline \multirow[t]{4}{*}{ age group } & \multirow[t]{2}{*}{$21-40$} & Count & 0 & 0 & 138 & 138 \\
\hline & & $\%$ within age group & $.0 \%$ & $.0 \%$ & $100.0 \%$ & $100.0 \%$ \\
\hline & \multirow[t]{2}{*}{ above 40} & Count & 83 & 2 & 53 & 138 \\
\hline & & $\%$ within age group & $60.1 \%$ & $1.4 \%$ & $38.4 \%$ & $100.0 \%$ \\
\hline
\end{tabular}




\begin{tabular}{|c|c|c|c|c|c|}
\hline Total & $\begin{array}{l}\text { Count } \\
\% \text { within age group }\end{array}$ & $\begin{array}{r}83 \\
30.1 \%\end{array}$ & $\begin{array}{r}2 \\
.7 \%\end{array}$ & $\begin{array}{r}191 \\
69.2 \%\end{array}$ & $\begin{array}{r}276 \\
100.0 \%\end{array}$ \\
\hline
\end{tabular}

Finding: As per the analysis of Chi-square test the calculated value of Chi-square with $95 \%$ level of confidence is 0.000 which is less than level of significance i.e. 0.05 . So there is significant difference in life style of respondents when it is compared with age group of respondents between $20-40$ years \& above 40 years with the responses of the statement that I must have the latest model of mobile, no matter if I don't use many of the high tech. Features.

\begin{tabular}{|c|c|c|c|}
\hline \multicolumn{4}{|c|}{ Chi-Square Tests } \\
\hline & Value & Df & $\begin{array}{l}\text { Asymp. Sig. (2- } \\
\text { sided) }\end{array}$ \\
\hline Pearson Chi-Square & $1.228 \mathrm{E} 2^{\mathrm{a}}$ & 2 & .000 \\
\hline Likelihood Ratio & 157.022 & 2 & .000 \\
\hline Linear-by-Linear Association & 122.126 & 1 & .000 \\
\hline $\mathrm{N}$ of Valid Cases & 276 & & \\
\hline
\end{tabular}

a. 2 cells (33.3\%) have expected count less than 5. The minimum expected count is 1.00 .

Interpretation: Women in the age group of 21-40 want to the latest model of mobile even if they don't use many of its high tech features. It is seen earlier that women in this age group are earning a good salary and don't wish to save for the future. Moreover they have the desire to spend on products having public view is clearly seen in the women of this age group. This lifestyle change will increase the consumption of latest models of mobile $i$ the market.

Hypothesis No.9:

HO: There is no significant difference between age of the respondents and the wish to have their house in a posh colony as compared to a place close to the market or work place. $(\mu=3)$

H1: There is significant difference between age of the respondents and the wish to have their house in a posh colony as compared to a place close to the market or work place. $(\mu \neq 3)$

age group * mposh Cross tabulation

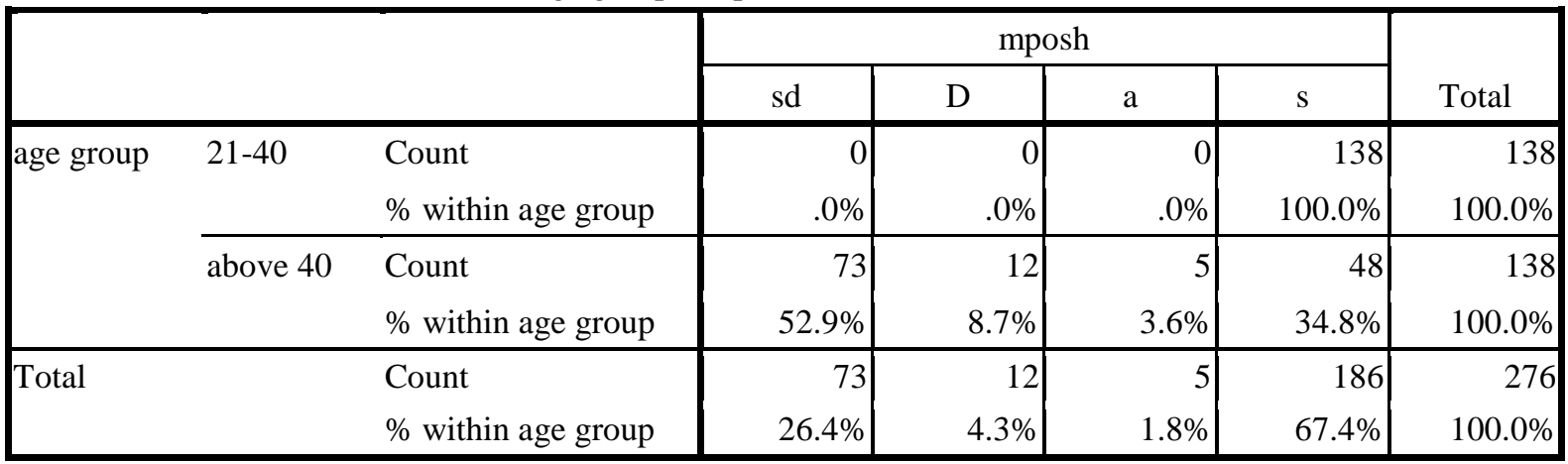

\begin{tabular}{|l|r|r|r|}
\hline \multicolumn{1}{|c|}{ Chi-Square Tests } \\
& \multicolumn{1}{|c|}{ Value } & df & \multicolumn{1}{c|}{$\begin{array}{c}\text { Asymp. Sig. (2- } \\
\text { sided) }\end{array}$} \\
\hline Pearson Chi-Square & $1.335 \mathrm{E}^{\mathrm{a}}$ & 3 & .000 \\
Likelihood Ratio & 170.197 & 3 & .000 \\
Linear-by-Linear Association & 125.664 & 1 & .000 \\
$\mathrm{~N}$ of Valid Cases & 276 & & \\
\hline
\end{tabular}

Finding: As per the analysis of Chi-square test the calculated value of Chi-square with 95\% level of confidence is 0.000 which is less than level of significance i.e. 0.05 . So there is significant difference in life style of respondents when it is compared with age group of respondents between $20-40$ years \& above 40 years with the responses of the statement I want my house to be in a posh colony as compared to a place close to the market or work place. 
Interpretation: Women in the age group of 21-40wish to have their house in a posh colony as compared to a place close to the market or work place. We see that although most of the women in this age group are working and do not have to spend with heir families, still heir inclination is not to live close to the market place or their work place. They want to live in a posh colony. This is in coherence with the desire of women to spend on products having public view. It shows that the younger generation is more status conscious.

Analysis of the study indicates that out of total women respondents most of the women in the 21-40 age group have a different orientation towards various questions asked as compared to women above 40 years of age. Group one are more bent towards spending as compared to group two. Although women consumers buy cheap goods but they are loyal for same type of commodity. On the time the buying goods most of the women in group one are more conscious of quality than the price

\section{Conclusions \& Suggestions}

With the help of findings of the study I conclude that there has definitely been a change in the lifestyle of women. This change is probably due to the fact that the women are earning more now and have increasing financial power.

In the previous decades the salary of women constituted a small part of the total annual household income. But the earning of women hold a greater proportion in the annual household income now. The women feel more confident in spending now because of a greater discretionary income which women use to satisfy their wants.

Her criteria for family purchases have been modified by her increased exposure to new ideas and information. Now she is playing a new role as a facilitator. Previously, the Indian women concentrated on purchases that based on family needs and wants. The marketers should understand the changing perception of women so that they are able to sell products more suited to the needs and wants began to gain ground. Thus it is high time that the marketers and manufacturers realize, understand and recognize women as a lucrative consumer segment and start developing concepts and create products that are women centric, which reap high growth potential.

\section{References}

[1]. Martha Barlett, CEO of Trendsight Group, a marketing Consultancy firm "Marketing to Women" -Advertising express - ICFAI

[2]. Philips, Hugh, How customers actually shop, Journal of Market Research Society, January 1993, Vol 35 Issue 1, pp 51 - 62.

[3]. Simintiras, Pre-purchase satisfaction and first time buying behavior, European Journal of Marketing, 1997, Vol 31 issue 11/12, pp 737 $-872$.

[4]. Bandyopadhyay, S. (2001). Competitiveness of foreign products as perceived by consumers in the emerging Indian market. Competitiveness Review, 11(1), 53-64.

[5]. Shainesh, Understanding buying behavior, International Journal of Technology Management, 2004, Vol 28 issue 1, pp 118 - 127.

[6]. Dr.Mu.Subrahmanian, "buying behavior of the new aged Indian women" Indian Journal of Commerce \& Management Studies, Vol-II , Issue -1 January 2011. 